\title{
Effect of Heavy Rates of Fertilization on Beef Production and Carrying Capacity of Napier Grass Pastures over 5 Consecutive Years of Grazing Under Humid Tropical Conditions ${ }^{1,2}$
}

\author{
Rubén Caro-Costas and José Vicente-Chandler"3
}

\section{INTRODUCTION}

Napier grass (Pennisetum purpureum) is widely used as cut forage throughout the Tropics but rarely is grazed. Caro, Vicente-Chandler and Figarella (5) found, however, that well-fertilized Napier, Guinea and Pangola grass pastures in the humid mountain region of Puerto Rico produced similar high yields averaging 1,065 pounds of gain in weight and 7,559 pounds of total digestible nutrients per acre yearly. Also, Caro, Vicente-Chandler and Burleigh (4) found that well-fertilized, irrigated Guinea and Napier grass pastures on the semiarid South Coast of Puerto Rico produced similar high yields averaging 1,310 pounds of gain in weight and 9,530 pounds of total digestible nutrients per acre yearly. Caro and Vicente-Chandler (2) found that increasing fertilization of Napier grass pastures from 600 to 1,800 pounds of 14-4-10 per acre yearly increased gains in weight from 570 to 1,072 pounds and total digestible nutrients from 4,160 to 7,190 pounds per acre yearly, and protein content of the forage consumed by the cattle from 8.1 to 15.9 percent.

The present study determined the effect of three heavy rates of fertilization on the carrying capacity and gains in live weight from intensively managed Napier grass pastures on steep slopes in the humid mountain region of Puerto Rico.

\section{MATERIALS AND METHODS}

The experiment was conducted over a 5-year period at Orocovis, which has a mean annual temperature of about $75^{\circ} \mathrm{F}$., and a seasonal variation of less than $10^{\circ} \mathrm{F}$. The soil is a deep, red, well-drained Humatas clay

1 Manuscript submitted to Editorial Board August 25, 1971.

2 This paper reports the results of research conducted cooperatively between the Soil and Water Conservation Research Division, Agricultural Research Service, USDA, and the Agricultural Experiment Station, Mayagüez Campus, University of Puerto Rico, Río Piedras, P.R.

Agronomist, cooperative between SWCRD, ARS, USDA, and the Agricultural Experiment Station, Mayagiiez Campus, University of Puerto Rico, and Project Leader-Soil Scientist, SWCRD, ARS, USDA, RIo Piedras, P.R., respectively. 
(Ultisol) on 35-percent slopes. The surface 6 inches had a 3.5-percent organic matter content; a pH of 5.2, 16.5 meq. of exchange capacity, and 10.4 meq. of exchangeable bases per $100 \mathrm{~g}$. of soil; a volume weight of about 1, with 11 percent of the pores drained at a tension of $60 \mathrm{~cm}$. of water, and a saturated percolation rate of about 4 inches per hour.

Fertilizer levels of $1,600,2,800$ and 4,000 pounds of $14-4-10$ fertilizer per acre were applied annually in four equal applications. All treatments were replicated four times in a randomized block design using 12 half-acre pastures of Napier grass. The rectangular pastures sloped downward from the top of a ridge, where shade and salt blocks were available, to a small creek with abundant water. The pastures were mowed once a year and were limed to about pH 5.5.

The pastures were grazed by young cattle weighing initially about 400 pounds which were replaced every 12 months. Holstein heifers were used during the first 3 years and bulls, implanted with $24 \mathrm{mg}$. of Dieth Stilbestrol every 6 months, during the following 2 years. Two, $21 / 2$ and 3 "tester" cattle, animals which remain on the pasture for a full year, were kept per acre at all times on the pastures receiving $1,600,2,800$ and 4,000 pounds of fertilizer per acre yearly, respectively. Additional animals were added to each group as required to consume excess forage produced during seasons of flush growth using the well-known "put-and-take" method. The cattle received no supplemental feed.

Cattle were moved from one pasture to another of the same level of fertilization when essentially all the leaves had been eaten from the stalks. On the average, the pastures were grazed for one week followed by a three-week rest period.

Cattle were weighed each time they were moved from one enclosure to another and a record was kept of the number of grazing days, animal weights, and gains in weight for each pasture. The total digestible nutrients produced, and carrying capacities of each pasture, were calculated from these data following recommendations of the Pasture Research Committee (1).

\section{RESULTS AND DISCUSSION}

The following tabulation shows annual rainfall during the experiment. Rainfall was well distributed throughout the year except for the normal January through March dry period.

1965

1966

1967

1968

1968

Inches of rainfall

$\begin{array}{lllll}79.5 & 72.8 & 62.4 & 73.6 & 100.6\end{array}$ 
The Napier grass pastures remained free of weeds throughout the experiment, showing that this vigorous grass competes successfully with weeds when properly fertilized.

Table 1 shows that these intensively managed Napier grass pastures responded strongly in beef production to each increment in fertilization up to 4,000 pounds per acre yearly. Over the 5 years of experimentation averaged liveweight production was $947,1,281$, and 1,582 pounds per acre yearly at the 1,600-, 2,800- and 4,000-pound fertilizer rates, respectively. Production of the pastures did not vary much from year to year, except during 1967, when low rainfall decreased yields at all levels of fertilization.

Under the conditions of this experiment it was economical to increase fertilization from 1,600 to 4,000 pounds per acre yearly. Each 1,200-pound increment in fertilization, costing about $\$ 48$ including cost of application,

TABLE 1.-Effect of three heavy rates of fertilization on gains in weight produced by intensively managed Napier grass paslure on sleep slope over 5 consecutive years of grazing at Orocovis (1965-1969)

\begin{tabular}{|c|c|c|c|c|c|c|c|}
\hline \multirow{2}{*}{$\begin{array}{l}\text { Fertilizer } \\
\text { (14-4-10) } \\
\text { applied per } \\
\text { acre yearly }\end{array}$} & \multicolumn{5}{|c|}{ Gains in weight per acre yearly } & \multirow{2}{*}{$\begin{array}{c}\text { Average } \\
\text { of } 5 \\
\text { years }\end{array}$} & \multirow{2}{*}{$\begin{array}{c}\text { Average daily } \\
\text { gains per } \\
\text { head of tester } \\
\text { cattle }\end{array}$} \\
\hline & $\begin{array}{c}1 \mathrm{st} \\
\text { year }\end{array}$ & $\begin{array}{l}\text { 2nd } \\
\text { year }\end{array}$ & $\underset{\text { year }}{\text { 3rd }}$ & $\begin{array}{l}\text { 4th } \\
\text { year }\end{array}$ & $\begin{array}{l}\text { 5th } \\
\text { year }\end{array}$ & & \\
\hline \multicolumn{8}{|c|}{ Pounds } \\
\hline 1,600 & 942 & 1,055 & 787 & 1,068 & 883 & 947 & 1.35 \\
\hline 2,800 & 1,254 & 1,454 & 1,001 & 1,329 & 1,368 & 1,281 & 1.30 \\
\hline \multirow[t]{2}{*}{4,000} & 1,568 & 1,646 & 1,192 & 1,807 & 1,698 & 1,582 & 1.29 \\
\hline & & & & & L.S.D. 05 & 246 & N.S. \\
\hline
\end{tabular}

and a required liming produced about 300 pounds of additional gain in weight worth about $\$ 90$ at current farm prices. Heavy fertilization did not pay, however, during the dry year of 1967.

The average production of 1,582 pounds of liveweight per acre yearly obtained with 4,000 pounds of fertilizer is worth about $\$ 475$ at current prices or $\$ 315$ above fertilizer costs, a high income from such steep lands having few alternative uses. Also, these pastures would provide all the nutrients required to feed two cows per acre, producing a total of 5,000 liters of milk yearly with a current farm value of about $\$ 1,000$. Caro and Vicente-Chandler (3) have shown that cows producing over 2,500 liters of milk yearly can be fed on an all-grass ration from steep, intensively managed grass pastures such as these.

Average daily gains per head of about 1.3 pounds (table 1) were not affected by levels of fertilization and are considered good for young animals on all-grass rations. 
Table 2 shows that total digestible nutrients consumed by the cattle and carrying capacity of the pastures increased with rate of fertilization. At the 4,000-pound rate of fertilization the pastures on the average carried the equivalent of $3.58,600$-pound steers per acre or 2.52 standard beef cows throughout the year with never less than three head per acre at any time.

\section{SUMMARY}

Intensively managed Napier grass pastures on steep slopes in the humid mountain region of Puerto Rico grazed by young growing cattle over a 5 -year period, produced an average of 947, 1,281 and 1,582 pounds of gain

TABLE 2.-Effect of three heavy rates of fertilization on tolal digestible nutrient production and carrying capacity of inlensively managed Napier grass pasture on sleep slopes over 5 consecutive years of grazing in Orocovis (1964-1970)

\begin{tabular}{|c|c|c|c|c|c|}
\hline \multirow{2}{*}{$\begin{array}{l}\text { Fertilizer } \\
\text { (14-1-10) } \\
\text { applied per } \\
\text { acre yearly }\end{array}$} & \multicolumn{2}{|c|}{$\begin{array}{l}\text { Total digestible nutrients } \\
\text { produced per acre yearly }{ }^{1}\end{array}$} & \multicolumn{2}{|c|}{ Carrying capacity } & \multirow{2}{*}{$\begin{array}{c}\text { Minimum } \\
\text { number of } \\
\text { cattle kept } \\
\text { per acre } \\
\text { throughout } \\
\text { the year }\end{array}$} \\
\hline & $\begin{array}{c}\text { Average } \\
\text { of } 5 \\
\text { years }\end{array}$ & $\begin{array}{c}\text { Maximam } \\
\text { annual } \\
\text { variation }\end{array}$ & $\begin{array}{c}\text { Standard } \\
\text { beef } \\
\text { cows } 5^{2}\end{array}$ & $\begin{array}{c}600- \\
\text { pound } \\
\text { steers }\end{array}$ & \\
\hline Pounds & Pounds & Pounds & $\begin{array}{l}\text { Beods/ } \\
\text { Acre }\end{array}$ & $\begin{array}{c}\text { Beads/ } \\
\text { Acre }\end{array}$ & \\
\hline 1,600 & 6,890 & $5,975-7,315$ & 1.56 & 2.22 & 2.0 \\
\hline 2,800 & 8,960 & $7,625-9,930$ & 2.04 & 2.89 & 2.5 \\
\hline 4,000 & 11,100 & $9,560-11,980$ & 2.52 & 3.58 & 3.0 \\
\hline L.S.D.05 & 1,260 & & 0.29 & 0.41 & - \\
\hline
\end{tabular}

1 Calculated from body weights, days of grazing, and gains in weight following recommendation of the Pasture Research Committee (1).

2 One standard beef cow $=12$ pounds T.D.N. daily.

${ }^{3}$ One 600 -pound steer $=8.5$ pounds T.D.N. daily.

in weight per acre yearly when fertilized annually with $1,600,2,800$ and 4,000 pounds of 14-4-10 fertilizer per acre, respectively. The pastures carried the equivalent of 2.22-, 2.89- and 3.58 six-hundred-pound steers per acre throughout the year and produced $6,890,8,960$ and 11,100 pounds of total digestible nutrients per acre yearly at the $1,600-, 2,800$ - and 4,000pound fertilizer levels, respectively. Daily gains per head were not affected by level of fertilization, and averaged 1.31 pounds. At the 4,000-pound fertilizer rate the pastures maintained a minimum of 3 head per acre and produced 1,582 of liveweight worth about $\$ 475$ at current prices or $\$ 315$ above fertilizer costs.

\section{RESUMEN}

Pastos de yerba Napier bajo cultivo intensivo en terrenos inclinados de la región montañosa de Puerto Rico produjeron un promedio de 947, 1,281 y 1,582 libras de 
ganancia en peso por acre al año cuando se les aplicaron $1,600,2,800$ y 4,000 libras del abono 14-4-10 por acre al año, respectivamente. Los pastos mantuvieron en promedio el equivalente la $2.82,2.89$ y 3.58 novillos de 600 libras de peso por acre y produjeron $6,890,8,960$ y 11,100 libras de nutrimentos digeribles por acre al año cuando se les aplicaron $1,600,2,800$ y 4,000 libras de abono de la fórmula 14-4-10 por acre por año, respectivamente. El ganado aumentó en promedio 1.31 libras por día independientemente del nivel de abonamiento. Cuando se aplicaron 4,000 libras de abono los pastos mantuvieron un mínimo de 3 cabezas por acre durante todo el año y produjeron un promedio de 1,582 libras de aumento en peso al año valoradas en $\$ 475$.

\section{LITERATURE CITED}

1. Anonymous, Report on Pasture and Range Research Techniques, Joint Committee - of ASA, ASAP, ADSA, and ASRM, Agron. J. 44 (1): 39-50, 1952.

2. Caro-Costas, R., and Vicente-Chandler, J., Effect of fertilization on carrying capacity and beef produced by Napier grass pastures, Agronomy J. 53: 204-5, 1961.

3. - Milk production with all-grass rations from steep, intensively managed tropical pastures, J. Agr. Univ. P.R. 53 (4): 251-58, 1969.

4. - and Burleigh, C., Beef production and carrying capacity of heavily fertilized, irrigated Guinea, Napier, and Pangola grass pastures on the semiarid South Coast of Puerto Rico, J. Agr. Univ. P.R. 45 (1): 32-6, 1961.

5. - , and Figarella, J., Productivity of intensively managed pastures of 5 grasses on steep slopes in the humid mountain region of Puerto Rico, J. Agr. Univ. P.R. 49 (1): 99-111, 1965. 